\title{
A Good Supervisor-Ten Facts of Caring Supervision
}

\author{
Kaarina Määttä ${ }^{1}$ \\ ${ }^{1}$ Faculty of Education, University of Lapland, Rovaniemi, Finland \\ Correspondence: Kaarina Määttä, Faculty of Education, University of Lapland, PO Box 122, 96101 Rovaniemi, \\ Finland. Tel: 358-400-696-480. E-mail: Kaarina.Maatta@ulapland.fi
}

\author{
Received: March 16, 2015 Accepted: April 22, 2015 Online Published: August 27, 2015 \\ doi:10.5539/ies.v8n9p185 URL: http://dx.doi.org/10.5539/ies.v8n9p185
}

\begin{abstract}
This article describes the elements of caring supervision of doctoral theses. The purpose was to describe the best practices as well as challenges of supervision especially from the supervisor's perspective. The analysis is based on the author's extensive experience as a supervisor and related data obtained for research and developmental purposes. Caring supervision is summarized into ten facts that illustrate the multidimensional nature of a supervision relationship. The findings can help supervisors develop in their important work of supervising doctoral theses.
\end{abstract}

Keywords: supervision, doctoral thesis, $\mathrm{PhD}$ student, dissertation, caring

\section{Introduction}

The supervisor's role in supervising research and theses is a demanding and important one. When it comes to the supervision of doctoral theses, the positions and roles of supervisor and $\mathrm{PhD}$ students are even more unique. Still, many same roles that the supervisor adopts during supervision processes of any thesis are included in the supervision of $\mathrm{PhD}$ theses as well. The supervisor's roles vary from a guide to friend and critic, and everything in between.

Caring supervision of $\mathrm{PhD}$ theses has its own special features and presents a more student-centered approach than for example the concept of efficient supervision (Boud \& Lee, 2009; Cryer, 2003; Delamont et al., 2008; Dunleavy, 2003; Evans \& Kamler, 2005; Golde, 2007; Philips \& Pugh, 2003; Taylor \& Beasley, 2005). I will discuss them in detail in this article. First, I will introduce my background and experience with $\mathrm{PhD}$ theses.

I have supervised $60 \mathrm{PhD}$ theses at the Department of Education of the University of Lapland since 2002. I have described the dissertation processes and documented various phases of supervision and doctoral research work in the form of a researcher's diary (see also Määttä, 2012). Furthermore, some of my students ( $N=25)$ gave me their own written stories about their dissertation process. In addition, I corresponded with them by e-mail in hundreds of pages over the years during their dissertation processes. This is a review paper summarizing my findings based on the aforementioned data and practical experience as a supervisor.

My specific focus has been on the nodes of the doctoral dissertation process and on my action as a supervisor. I have been interested in the research process from a supervisor's point of view. What kinds of obstacles and drags the process includes that a supervisor especially could help smooth down? How can I as a supervisor support $\mathrm{PhD}$ students in their research processes? In summary, my purpose in this article is to answer the following question: What is caring supervision of doctoral theses?

For this purpose, I will use the data I have obtained during my years of a supervisor as described earlier. The communications used in the data are supervision conversations that took place in real supervision situations. As considered as a dialogue between a supervisor and a student, the original purpose of the supervision conversations was to enhance the work with thesis. I have asked every doctoral student for permission to use the data anonymously for this research purpose. All participants gave me permission to make their correspondence public. The data were analyzed with the content analysis method (Denzin, 1989). The main themes have been derived from the PhD students' stories and my own observations and experiences as well as reflections of my own supervision.

The purpose is to provide as much space as possible for my own perceptions alongside the PhD students' voices. At the same time, I will reflect on the results compared with previous research about the supervision of the 
doctoral theses and its problems.

\section{The Elements of Caring Supervision}

According to my interpretation, caring supervision of doctoral theses consists of ten facts. They lay the foundation of a good supervision relationship and research process. It is important to pay attention to these facts, although not even the best supervision can guarantee that a doctoral thesis will be finished. Ultimately, the PhD student is responsible for his or her solutions and choices (Shavelson, 2007). And still, a caring supervisor can be irreplaceable. The following ten themes can also help supervisors develop in their important work of supervising doctoral theses.

\subsection{Caring Supervision Is Sensitive Interaction}

Fundamentally, supervision is based on interaction and collaboration (see Wisker et al., 2003). This reciprocal relationship can be very sensitive and fragile, but it also has quite energizing and empowering features. Interestingly, all these features are experienced in mutual interaction between the supervisor and $\mathrm{PhD}$ student and, therefore, the depth and closeness of the relationship do not become very easily visible to other people (see Parry, 2007; Whitelock, Faulkner, \& Miell, 2008). The supervision relationship and the supervisor's and student's way of working together can also be model that is transmitted to the next researcher generation (Lindén, Ohlin, \& Brodin, 2013). However, it is possible to finish a dissertation process without abundant supervision, and on the other hand, some students need constant guidance and still do not ever reach the ultimate goal of graduation as a doctor.

A doctoral dissertation as the highest academic thesis is always a proof of the $\mathrm{PhD}$ student's profound studies and skills (Dill et al., 2006; Green \& Powell, 2005). A supervisor can encourage the student and help him or her make it to the top achievement. A good supervisor is also capable of supporting and strengthening the emerging talent in $\mathrm{PhD}$ students. Along with experience, the supervisor can recognize the PhD students' need as well as obstacles of these future top researchers' research work.

The most far-reaching and rewarding aspect in supervision is to encourage talented researchers to use their abilities and expertise for the development of science. This can provide supervisors with opportunities to be creative and to perceive the influence of their work. A good supervision relationship and sensitive collaboration between the novice and senior researcher stimulates, gives new perspectives, and lead to new innovations in the supervisor's research work as well (Halse, 2011; Kearns, Gardiner, \& Marshall, 2008).

Every $\mathrm{PhD}$ student becomes to know that the dissertation process will require plenty of initiative, familiarization, and toil. Although the work can be merely overestimated than underestimated, the supervisor should evaluate the student's preparedness and commitment to $\mathrm{PhD}$ studies. It is unnecessary for the supervisor to engage in supervision without the student's own engagement and enthusiasm. Both of them must be certain about the significance of the research.

A dissertation process does not happen just in the collaboration between the supervisor and the PhD student. Although the completed thesis is the PhD student's great achievement, numerous other people have also contributed to it. Support is given and especially needed from the student's family and friends, but also from colleagues and employer. The university and academic world offer several beneficial services as well, such as library services as well as conferences and seminars (see Eraut, 2004; Boud \& Lee, 2005).

The seminars are beneficial because there students can safely talk about and share their thoughts with their peers who can comment on them and related solutions, and even give new ideas (Llado et al., 2014). The supervisor has a crucial role in creating a supportive atmosphere in the seminar and familiarizes $\mathrm{PhD}$ students with the research culture in their own field. Then, the students are socialized in the prevailing norms and standards in the field (Ferguson, 2009).

\subsection{The Emphases of Caring Supervision Change during the Process}

A doctoral research has its ups and downs, and critical nodes. This necessitates that foci and elements of supervision change during the process as well. First the research theme as well as concepts become specified (Golde, 2000; Rae, 2002). After deciding these fundamental directions, the PhD student can start familiarizing with the theory, methodology, and practice related in the research theme (McWilliam et al., 2005).

The first encounters, conversations, and moments with a supervisor are determining factors at the beginning. Often, the student is shy and doubtful of his or her research abilities. If the student finds the supervisor caring, he or she is likely to start having belief in his or her chances. A caring supervisor supports the students, shows interest in and appreciates the student's plans, and spares also time and give suggestions to enhance the quality of 
the research plan (Kumar \& Stracke, 2007).

During the research process, the supervision relationship changes. The initial sense of appreciation can become deeper, turn into friendship, or change toward an opposite direction, into collaboration between colleagues. Disagreements cannot be always avoided either (Wright \& Cochrane, 2000).

The professionalism of a caring supervisor becomes evident by not abandoning or leaving $\mathrm{PhD}$ students in trouble; not even when experiencing that the value of the supervision has not been appreciated at all. A caring supervisor understands and is able to predict the powerful impact the research work and the dissertation process can have on the student. Particularly, when working hard, at the limits of disappointment and fatigue, the supervisor's sincere and unwavering support is invaluable to students. The special value of caring supervision in manifested in the $\mathrm{PhD}$ student's trust in the supervisor staying on his or her side even when the progress is tangling or slow (Ellis \& Shockley-Zalabak, 2001; Willemyns, Gallois, \& Callan, 2003).

As the doctoral research and the contents of the thesis develop, the ability to supervise and become supervised set a constant challenge. The work changes continuously due to new choices, reflections, and pendulum of options. The initial foci may not necessarily be functional at the end, even if their seemed so clear at the beginning - both in the supervisor's and $\mathrm{PhD}$ student's eyes. The final thesis is invariably just a shade of the initial research idea.

\subsection{A Caring Supervisor Does Not Hold Back Compliments and Appreciation}

The research process takes $\mathrm{PhD}$ students to the edges of their limits. Successes make them happy, while revision needs can frustrate. However, students are quite happy to admit and work with many deficits if the criticism is expressed alongside positive feedback and appreciative comments on the elements of the research. Therefore, a caring supervisor should not underestimate the value of compliments (see Berg \& Dejong, 2005).

Actually, the well-written parts of a thesis may easily be disregarded as self-evident. A supervisor can assume that the PhD student already knows his or her good sides as an author, researcher, and expert in the field. Even if meaning good and trying to motivate the student, the supervisor can tend to focus on the limitations and weaknesses without noticing the strengths of the work sufficiently.

A caring supervisor uses words of compliments being aware of their inspiring meaning and even consciously looks for successes on which base the positive feedback. It is hardly impossible to give too much positive feedback, which can become determining comments during the difficult phases of the research work and writing the thesis. In addition to the positive interaction and atmosphere in supervision, the structural clarity is important (Atkins \& Brown, 1988).

It is also important that the $\mathrm{PhD}$ student thanks the supervisor for insightful comments, time spent with his or her research, and conversations or useful viewpoints. This can be energizing to the supervisor and make him or her want to make the student's process smooth and avoid unnecessary sidetracks. Still, a straight path may not be easily found and accomplishing the goal necessitates humility and careful introspection from the supervisor and the student. The greatest reward is thanking, which can be said and experienced reciprocally (Lindén, Ohlin, \& Brodin, 2013).

\subsection{A Caring Supervisor Motivates to Write}

Writing cannot be emphasized too much in the supervision of $\mathrm{PhD}$ theses. There is no short cut to how to learn to be an excellent writer. Often, reasonable advice for a $\mathrm{PhD}$ student is to assure that hardly anyone writes finished text at once, but writing takes numerous rounds of revisions and re-organizations (Aitchison \& Lee, 2006).

A supervisor can take the reader's role and estimates whether the text is understandable to readers who are not familiar with the study beforehand. It is quite usual that $\mathrm{PhD}$ students find it problematic to write clearly about their own research solutions and related choices made during the process. When writing for the academic audience, the most important guideline is to avoid vagueness. In the scientific discussion, there is no room for different interpretation but every choice made has to be excplicitly explained in the thesis (Kamler, 2008).

Indeed, PhD students frequently are worried about their writing work and may find it impossible to type words. The best solution to this problem is to encourage them to write those sections that they consider the easiest to address at that moment. There are always parts that should be written anyway, and therefore, the words may start to roll in when the first threshold is conquered (Booth, Clombs, \& Williams, 2003).

The interconnectedness of writing and thinking is manifested in the way the text reveals the researcher's reasoning, and therefore, keeping up the rhythm of writing is crucial furing the research work (Paltridge \& Starfield, 2008). 
Likewise, the supervisor has to be prepared to read differently various students' texts; while some need to be merely assured of their direction, others will benefit from a more detailed reading and feedback already at the beginning of their writing work. Learning writing skills never ends; there is always something to improve and practice, and, here, caring feedback can be of great help (see Murray \& Moore, 2006).

\subsection{Caring Supervision Clarifies the Requirement of PhD Research}

$\mathrm{PhD}$ students easily tend to think that the demands and expectations set for a doctoral thesis are overwhelming (see Mullins \& Kiley, 2002). To prevent these thoughts taking too big a role during the research process, constant communication between a supervisor and a $\mathrm{PhD}$ student is needed. Sometimes, students are afraid of bothering their supervisors too often or with matters they consider minor. On the other hand, students do not always have words to explain issues holding back their progress but which caring supervisors can be able to identify when talking or communicating otherwise with the students. PhD students who work hard with their theses will find the supervisor's caring inquiries about their progress encouraging and helpful.

Caring supervision means that the supervisor gives time to $\mathrm{PhD}$ students. If communication has long delays, many matters or problems will change or lose their topicality. Creating an open interaction and reciprocal, prompt manner of communicating can prevent the research process from sidetracking (Wright \& Cochrane, 2000).

\subsection{A Caring Supervisor Teaches Time Management}

A supervisor has to accept the fact and be aware of that students use their time very differently. A schedule for working with a doctoral thesis will help planning and organizing the phases and contents of research work and writing. The doctoral research process is peculiar because it does not usually involve any particular deadline. This is also one reason why the processes progress differently; students do differ quite much on their ability to push themselves to work. However, when the finish line looms, most students want to advance their work at full speed; their work manifests inspiration and sense of expertise (Doncaster \& Lester, 2002; Malfroy \& Yates, 2003; Murray \& Lawrence, 2008; Ryan \& Deci, 2000). Some students become overwhelmed by their aspiration to get the work done. Too tight a schedule can turn into burden or stress. At their worst, they can staunch the writing work totally, and the fluent working at the beginning can turn into awkward or clumsy presentation. This can be the result of trying too much, too perfect, and too quickly. The solution, however, may seem simple. The caring supervisor can help the PhD student see that it is time to slow down and call a time out. Still even, the supervisor may lose the sense of speed (Delamont, Atkinson, \& Parry, 2000; Philips \& Pugh, 2000).

A caring supervisor is able to notice students' various life situations and changes in their motication. They cannot have similar goals when it comes to scheduling of the work. The doctoral research is not necessarily the only content of life, and progress in doctoral studies can require time for family, hobbies, and other work tasks as well. Some students focus on research intensively, prioritizing it in their lives. Some others proceed more peacefully alongsider day jobs and other areas of life.

\subsection{A Caring Supervisor Helps Tolerate Uncertainty and Criticism}

Students also differ in their ability to accept criticism and advice. Some will be more easily disappointed or offended than others. The risk of a PhD student quitting the work is always possible. The supervisor has to evaluate how to help sensitively and constructively the student, and also show appreciation. Many supervisors think how to be critical but encouraging to students when they dissect their research (Caffarella \& Barnett, 2000).

Usually, PhD students are prepared to criticism and know how evaluations make an important part of scientific work. Still, criticism can be surprisingly hurting, and probably everyone has to experience disappointments and frustrations at some point. It is normal - and understandable - that students tend to defend themselves and underestimate revisions. The core of caring supervision is to mold criticism and problems in the thesis into concrete revisions suggestions. Then, criticism seems like feedback that can improve the research (Cullen et al., 1994). All this requires humbleness not only from the student but also from the supervisor as well. Caring supervision means constant learning and renewal (Costley \& Stephenson, 2009).

Indeed, the supervisor can experience uncertainty during the supervision process too. Admitting this can help the $\mathrm{PhD}$ student understand the nature of research work: there are not ready solutions while optional routes are abundant. Caring supervision maintains sensitivity and openness to various solutions. The right direction is found in the ability to justify the choices made (Stracke \& Kumar, 2010). 


\subsection{A Caring Supervisor Monitors the Fulfillment of the Quality Criteria of a Doctoral Thesis}

A supervisor has a special responsibility in the dissertation process. He or she has to evaluate the progress of a thesis in the light of the criteria set by the academic community (see Golde, 2000). A PhD thesis is a research-based, scientific presentation in one of the academic fields. It is to show the student's ability to apply scientific research methods independently and critically, and to create new scientific information. The doctoral thesis should fulfil the following criteria of scientific contribution and the student's scholarship and ability. It has to (a) include new scientific information and well-developed results and be scientifically convincing; (b) show the candidate's ability to critical thinking, deep familiarization with one's academic field, and knowledge of scientific research methods and their application; and be scientifically honest and follow the research ethical guidelines (Golding, Sharmini, \& Lazarovitch, 2014).

Sometimes, it is necessary to clearly emphasize that the thesis is not made for the supervisor and who therefore cannot close eyes from the problems in the thesis. The deficits have to be addressed sooner or later: after unfavoring pre-examination statements, the revision work can be laborious to the student and the supervisor as well. Certainly, the supervisor can become blind to the text too; when focusing on some parts of the thesis, the supervisor can disregard other significant issues that are commented by pre-examiners, for a good reason.

A PhD student has to be able to trust a supervisor's opinions when assessing the quality of a thesis (Kearns, Gardiner, \& Marshall, 2008). For a student, it is difficult to know when the thesis is ready for pre-examination, and thus, the supervisor should point out the strengths and weaknesses of the work. Still, the student has the ultimate responsibility for putting the thesis to the official review. Realizing the possible deficits in the thesis, the student likely finds it easier to wait for the pre-examiners' statements and to revise the thesis according to them (see Winter, Griffiths, \& Green, 2000).

\subsection{A Caring Supervisor Provides Many Kinds of Feedback}

The feedback and suggestions the supervisor provides to the $\mathrm{PhD}$ students require many kinds of expertise, too. Thus, the writing talent is necessary for a supervisor if aiming at giving clear written directions. The purpose of feedback is to provide concrete advice and to enhance the smooth progress of the student's PhD research. Still, students accept feedback differently, which can, however, depend on a supervisor's skills of giving it, too (Cho, Schunn, \& Charney, 2006). Caring supervision includes repetitions, feedback giving both verbally and literally, as well as making sure that the feedback was received and understood (Tracy, 1997).

According to my experience, written feedback has its special benefits. Emails and papers can be saved and returned whenever needed. This makes it possible to consider and make choices based on the feedback in peace, and also check the way the notes are understood. The risk of misunderstandings should never be underestimated. Therefore, supervision meetings and comparing notes together are invaluable.

Caring supervision leans on constructive feedback. Everyone's work has strengths that can be highlighted first during each supervision meeting. The feedback will always focus on the text and study, not on the student as a person. An accepting and encouraging atmosphere is the key because it also allows the feedback be honest and respectful. Feedback meetings should be arranged regularly. At its best, a supervising meeting ends with a mutual understanding of how the student proceeds next. It is important to sum up to correct any misreading (Ellis \& Shockley-Zalabak, 2001).

\subsection{Caring Supervision Provides Suggestions and Options, in Addition to Questions}

It is important that a supervisor has the ability to ask, but, more often than not, that is not enough (Lea \& Street, 2000). Although good questions make a student focus on and ponder various parts of the work, these questions will be better concretized if a supervisor is able to suggest alternatives. Fundamentally, the student is the one making decisions concerning the research, but examples and suggestions can help with the task.

The language used in supervision and the questions concerning a thesis change during a dissertation process. A caring supervisor tries to find ways to guide the process that do not overwhelm the student (Watkins \& Scaturo, 2014). Even the correction suggestions can be divided and suggested one section at a time (cf., Tepper, 2000). This kind of piecing of the work can make the progress smoother and prevent unnecessary work.

\section{Conclusion}

The ten elements described in this article illustrate the various sides of caring supervision. It becomes evident that supervision means also the supervisor's self-reflection, testing of one's limits, and being able to change even supervising methods that he or she has previously found good. A caring supervisor has to constantly evaluate what he or she is capable of as a supervisor, how to inspire the student to toil and persevere, and to marvel their 
own abilities.

A committed supervisor can find the work the most satisfying and self-fulfilling when realizing the core of supervision relationship. Supervision of doctoral theses fulfills the core features of meaningful and appropriately challenging work allowing plenty of opportunities to develop personally and professionally (e.g., Uusiautti \& Määttä, 2011). Caring supervision can even lead to the so-called "perfect storm" that can turn into a much deeper and more personal engagement with the supervisor's work (see e.g., Flint, Kurumada, Fisher, \& Zisook, 2011). Successes and personal development in supervision boost positive experiences that are important to the supervisor's coping as well. Rimé (2009) has stated that positive emotions enhance individual well-being by the increase of the level of positive affect that they entail and by the positive feedback that a successful experience brings about one's action. This way caring supervision cares for the supervisor, too (Halse, 2011).

The nature and importance of the supervision relationship has been studied relatively much. The relationship has been analyzed from many perspectives, for example, as a role relationship (Ellis \& Dell, 1986) or power relationship (Manathunga, 2007). In addition, students' (Heath, 2002) and supervisors' (Delamont, Atkinson, \& Parry, 2000) perceptions of good or failed supervision relationships have been studied. Several phases of the process or flaws in supervision can threaten or hinder the completion of the doctoral thesis (see Burton \& Hoobler, 2006; Grant 2005; Lian, Ferris, \& Brown, 2012). The approach introduced in this article can help overcoming many of this nodes and obstacles.

To conclude, caring supervision can help address the challenges and opportunities the work entails today and in the future. How do students perceive supervision during their dissertation processes (Health, 2002) or how do supervisors describe their supervision work (Johnson, 1997) are interesting questions that needs to be addressed and further studied as the number of doctoral theses increases and how their supervision has to adjust to the current requirements (see e.g., Park, 2005). Certainly, supervision practices will get new forms, but the core is still the interaction between the supervisor and student. That also makes supervision extremely fascinating. The relationship between a supervisor and a doctoral student is always one of a kind, as is each and every dissertation process. Still, the goal is the same; it is the way toward it that could be found in the tenets of caring supervision. Completing a doctoral thesis is a fantastic and immemorial experience for a $\mathrm{PhD}$ student and a supervisor. It is the pinnacle of caring supervision.

\section{References}

Aitchison, C., \& Lee, A. (2006). Research writing: Problems and pedagogies. Teaching in Higher Education, 11(3), 265-278. http://dx.doi.org/10.1080/13562510600680574

Atkins, M., \& Brown, G. (1988). Effective teacher in higher education. New York, NY: Routledge.

Berg, I. K., \& DeJong, P. (2005). Engagement through complimenting. Journal of Family Psychotherapy, 16(1-2), 51-56. http://dx.doi.org/10.1300/J085v16no1_11

Booth, W. C., Clombs, G. G., \& Williams, J. M. (2003). A craft to research. Chicago, IL: University of Chicago Press.

Boud, D., \& Lee, A. (Eds.) (2009). Changing practices of doctoral education. London and New York: Routledge.

Burton, J. P., \& Hoobler, J. M. (2006). Subordinate self-esteem and abusive supervision. Journal of Managerial Issues, 18(3), 340-355.

Caffarella, R. S., \& Barnett, B. G. (2000). Teaching doctoral students to become scholarly writers: The importance of giving and receiving critiques. Studies in Higher Education, 25(1), 39-52. http://dx.doi.org/10.1080/030750700116000

Cho, K., Schunn, C., \& Charney, D. (2006). Commenting on writing. Typology and perceived helpfulness of comments from novice peer reviewers and subject matter experts. Written Communication, 23(3), 260-294. http://dx.doi.org/10.1177/0741088306289261

Costley, C., \& Stephenson, J. (2009). Building doctorates around individual candidates'professional experience. In D. Boud, \& A. Lee (Eds.), Changing practices of doctoral education (pp. 171-186). London and New York: Routledge.

Cryer, R. (2003). The research student's guide to success. Maidenhead: Open University Press.

Cullen, D., Pearson, M., Saha, L. J., \& Spear, R. H. (1994). Establishing effective PhD supervision. Canberra: Autralian Government Publishing Service. 
Delamont, S., Atkinson, P., \& Parry, O. (2000). Supervising the PhD. A guide to success. London: Society for Research into Higher Education.

Denzin, N. (1989). Interpretative interactionism (Applied Social Research Methods Series, vol. 16). Newbury Park, CA: Sage.

Dill, D., Mitra, S., Jensen, H., Lehtinen, E., Mäkelä, T., Parpala, A., . . Saari, S. (2006). PhD training and the knowledge based society: An evaluation of doctoral education in Finland. International Postgraduate Students Mirror 2006. Helsinki: Finnish Higher Education Evaluation Council.

Doncaster, K., \& Lester, S. (2002). Capability and its development: Experiences from a work-based doctorate. Studies in Higher Education, 27(1), 91-101. http://dx.doi.org/10.1080/03075070120099395

Dunleavy, P. (2003). Authoring a PhD. How to plan, draft, write and finish a doctoral thesis or dissertation. Hampshire: Palgrave.

Ellis, K., \& Shockley-Zalabak, P. (2001). Trust in top management and immediate supervisor: The relationship to satisfaction, perceived organizational effectiveness, and information receiving. Communication Quarterly, 49(4), 382-398. http://dx.doi.org/10.1080/01463370109385637

Ellis, M. V., \& Dell, D. M. (1986). Dimensionality of supervisor roles: Supervisors' perceptions of supervision. Journal of Counseling Psychology, 33(3), 282-291.

Eraut, M. (2004). Informal learning in the workplace. Studies in Continuing Education, 26(2), 247-273. http://dx.doi.org/10.1080/158037042000225245

Evans, T., \& Kamler, B. (2005). The need for counter-scrutiny: Taking a broad view of doctoral education research. Higher Education Research and Development, 24(2), 115-118. http://dx.doi.org/10.1080/07294360500062805

Ferguson, T. (2009). The "write" skills and more: A thesis writing group for doctoral students. Journal of Geography in Higher Education, 33(2), 285-297. http://dx.doi.org/10.1080/03098260902734968

Flint, A. S., Kurumada, K. S., Fisher, T., \& Zisook, K. (2011). Creating the perfect storm in professional development: the experiences of two American teachers and a university research team. Professional Development in Education, 37(1), 95-109. http://dx.doi.org/10.1080/19415250903425502

Golde, C. M. (2000). "Should I stay or should I go?": Student descriptions of the doctoral attrition process. Review of Higher Education, 23(2), 199-227. http://dx.doi.org/10.1353/rhe.2000.0004

Golde, C. M. (2007). Signature pedagogies in doctoral education: are they adaptable for the preparation of $\begin{array}{lllll}\text { education } & \text { researches. } & \text { Educational 364-351. }\end{array}$ http://dx.doi.org/10.3102/0013189X07308301

Golding, C., Sharmini, S., \& Lazarovitch, A. (2014). What examiners do: What thesis students should know. Assessment \& Evaluation in Higher Education, 39(5), 563-576. http://dx.doi.org/10.1080/02602938.2013.859230

Grant, B. M. (2005). Fighting for space in supervision: Fantasies, fairytales, fictions and fallacies. International Journal of Qualitative Studies in Education, 18(3), 337-354. http://dx.doi.org/10.1080/09518390500092483

Green, H., \& Powell, S. (2005). Doctoral study in contemporary higher education. Buckingham: Open University Press.

Halse, C. (2011). 'Becoming a supervisor': The impact of doctoral supervision on supervisors' learning. Studies in higher education, 36(5), 557-570. http://dx.doi.org/10.1080/03075079.2011.594593

Heath, T. (2002). A quantitative analysis of PhD students' views of supervision. Higher Education Research \& Development, 21(1), 41-53. http://dx.doi.org/10.1080/07294360220124648

Johnston, S. (1997). Examining the examiners: An analysis of examiners' reports on doctoral theses. Studies in Higher Education, 22(3), 333-347. http://dx.doi.org/10.1080/03075079712331380936

Kamler, B. (2008). Rethinking doctoral publication practices: Writing from and beyond the thesis. Studies in Higher Education, 33(3), 283-294. http://dx.doi.org/1080/03075070802049236

Kearns, H., Gardiner, M., \& Marshall, K. (2008). Innovation in PhD completion: The hardy shall succeed (and be happy!). Higher Education Research \& Development, 27(1), 77-89. http://dx.doi.org/10.1080/07294360701658781 
Kumar, V., \& Stracke, E. (2007). An analysis of written feedback on a PhD thesis. Teaching in Higher Education, 12(4), 461-470. http://dx.doi.org/10.1080/13562510701415433

Lea, M., \& Street, B. (2000). Student writing and staff feedback in higher education: an academic literacy's approach. In M. Lea, \& B. Stieres (Eds.), Student writing in higher education. New contexts (pp. 32-46). Buckingham: Society for Research in Higher Education.

Lian, H., Ferris, D. L., \& Brown, D. J. (2012). Does power distance exacerbate or mitigate the effects of abusive supervision? It depends on the outcome. Journal of Applied Psychology, 97(1), 107-123. http://dx.doi.org/10.1037/a0024610

Lindén, J., Ohlin, M., \& Brodin, E. M. (2013). Mentorship, supervision and learning experience in $\mathrm{PhD}$ education. Studies in Higher Education, 38(5), 639-662. http://dx.doi.org/10.1080/03075079.2011.59526

Lladó, A. P., Soley, L. F., Fraguell-Sansbelló, R. M., Pujolras, G. A., Planella, J. P., Roura-Pascuale, . . Montoro-Morenog, L. (2014). Student perceptions of peer assessment: an interdisciplinary study. Assessment \& Evaluation in Higher Education, 39(5), 592-610. http://dx.doi.org/10.1080/02602938.2013.8600077

Määttä, K. (Ed.) (2012). Obsessed with the doctoral theses. Supervision and support during the dissertation process. Rotterdam: Sense Publishers.

Malfroy, J., \& Yates, L. (2003). Knowledge in action: doctoral programmes forging new identities. Journal of $\begin{array}{llll}\text { Higher Education Policy and } & \text { 119-129. }\end{array}$ http://dx.doi.org/10.1080/1360080032000122606

Manathunga, C. (2007). Supervision as mentoring: The role of power and boundary crossing. Studies in Continuing education, 29(2), 207-221. http://dx.doi.org/10.1080/01580370701424650

McWilliam, E., Lawson, A., Evans, T., \& Taylor, P. G. (2005). Silly, soft and otherwise suspect: doctoral education as a risky business. Australian Journal of Education, 49(2), 214-227. http://dx.doi.org/10.1177/000494410504900208

Mullins, G., \& Kiley M. (2002). "It's a phD, not a Nobel prize": How experienced examiners assess research theses. Studies in Higher Education, 28(49), 369-386. http://dx.doi.org/10.1080/0307507022000011507

Murray, L., \& Lawrence, B. (2008). The basis of critique of practitioner-based enquiry. In L. Murray, \& B. Lawrence (Eds.), Practitioner-based enquiry: Principles for postgraduate research (pp. 18-41). London: Falmer Press.

Murray, R., \& Moore, S. (2006). The handbook of academic writing. A fresh approach. New York, NY: Open University Press.

Paltridge, B., \& Starfield, S. (2008). Thesis and dissertation writing in a second language. A handbook for supervisors. London: Routledge.

Park, C. (2005). New variant PhD: The changing nature of the doctorate in the UK. Journal of Higher Education Policy and Management, 27(2), 189-207. http://dx.doi.org/10.1080/13600800500120018

Parry, S. (2007). Disciplines and doctorates. Dordrecht: Springer.

Philips, M., \& Pugh, D. (2003). How to get a PhD. A handbook for students and their supervisors. Maidenhead: Open University Press.

Rae, I. D. (2002). False start for the PhD in Australia. Historical Records of Australian Science, 14, 129-141. http://dx.doi.org/10.1071/HR02009

Rimé, B. (2009). Emotion elicits the social sharing of emotion: Theory and empirical review. Emotion Review, 1(1), 60-85. http://dx.doi.org/10.1177/1754073908097189

Ryan, R. M., \& Deci, E. L. (2000). Self-determination. Theory and the facilitation of intrinsic motivation, social $\begin{array}{llll}\text { development and } & \text { American }\end{array}$ http://dx.doi.org/10.1037/0003-066X.55.1.68

Shavelson, R. J. (2007). Assessing student learning responsibly: From history to an audacious proposal. Change: The Magazine of Higher Learning, 39(1), 26-33. http://dx.doi.org/10.3200/CHNG.39.1.26-33

Stracke, E., \& Kumar, V. (2010). Feedback and self-regulated learning: insights from supervisors' and $\mathrm{PhD}$ examiners' reports. Reflective Practice, 11(1), 19-32. http://dx.doi.org/10.1080/14623940903525140 
Taylor, S., \& Beasley, N. (2005). Handbook for doctoral supervisors. London and New York: Routledge.

Tepper, B. J. (2000). Consequences of abusive supervision. Academy of management journal, 43(2), $178-190$. http://dx.doi.org/10.2307/1556375

Tracy, K. (1997). Colloquium. Dilemmas of academic discourse. Advances in discourse processes 60. New Jersey, NJ: Ablex.

Uusiautti, S. \& Määttä, K. (2011). Love for work as the way towards well-being. Global Journal of Human Social Science, 11(9), 63-68.

Watkins Jr, C. E., \& Scaturo, D. J. (2014). Proposal for a common language, educationally-informed model of psychoanalytic Supervision. $\quad$ Psychoanalytic $\quad$ Inquiry, $619-633$. http://dx.doi.org/10.1080/07351690.2014.924374

Whitelock, D., Faulkner, D., \& Miell, D. (2008). Promoting creativity in PhD supervision: Tensions and dilemmas. Thinking Skills and Creativity, 3(2), 143-153. http://dx.doi.org/10.1016/j.tsc.2008.04.001

Willemyns, M., Gallois, C., \& Callan, V. (2003). Trust me, I'm your boss: Trust and power in supervisor-supervisee communication. International Journal of Human Resource Management, 14(1), 117-127. http://dx.doi.org/10.1080/09585190210158547

Winter, R., Griffiths, M., \& Green, K. (2000). The "Academic" qualities of practice: What are the criteria for a practice-based PhD? Studies in Higher Education, 25-37. http://dx.doi.org/10.1080/030750700115993

Wisker, G., Robinson, G., Trafford, V., Warnes, M., \& Creighton, E. (2003). From supervisory dialogues to successful PhDs: Strategies supporting and enabling the learning conversations of staff and students at postgraduate level. Teaching in Higher Education, 8(3), 383-397. http://dx.doi.org/10.1080/1356251030900

Wright, T., \& Cochrane, R. (2000). Factors influencing successful submission of PhD theses. Studies in Higher Education, 25(2), 181-195. http://dx.doi.org/10.1080/713696139

\section{Copyrights}

Copyright for this article is retained by the author(s), with first publication rights granted to the journal.

This is an open-access article distributed under the terms and conditions of the Creative Commons Attribution license (http://creativecommons.org/licenses/by/3.0/). 